\title{
Az Egészségbiztosítási Alap táppénzes trendjei Magyarországon 1997 és 2017 között
}

\author{
Nogel Mónika dr. \\ Széchenyi István Egyetem, Deák Ferenc Állam- és Jogtudományi Kar, Győr
}

\begin{abstract}
Bevezetés: A táppénz szerepe, hogy keresőképtelenség esetén az elveszített keresetet pótolja, biztosítsa, hogy a keresőképtelen személy egzisztenciális állapotában ne legyen törés.

Célkitüzés: Kutatásunk célja a táppénz igénybevételére és a táppénzkifizetésekre vonatkozó adatok feldolgozása volt az 1997 és 2017 közötti időszakra.

Adatok és módszerek: Kutatásunk a Nemzeti Egészségbiztosítási Alapkezelő (NEAK), a Központi Statisztikai Hivatal (KSH), és a Magyar Államkincstár (MÁK) adatsoraira, az Európai Bizottság Szociális Védelmi Bizottsága (SPC) és a Gazdasági Együttmúködési és Fejlesztési Szervezet (OECD) jelentéseire, továbbá a táppénzre vonatkozó jogszabályi környezet elemzésére épül.

Eredmények: 1997-ben 3,558 millió jogosultból 119 ezer, 1998-ban 3,530 millió jogosultból 114 ezer, 1999-ben 3,433 millió jogosultból 115 ezer, 2000-ben 3,465 millió jogosultból 112 ezer, 2006-ban a 3,523 millió jogosultból már csak 100 ezer, 2012-ben a 3,769 millió jogosultból 55 ezer fő volt táppénzen átlagosan naponta. 2017-re a jogosultak száma 4,018 millióra nőtt, ezzel párhuzamosan az egy napra jutó táppénzesek átlagos száma 70 ezer volt. A nem és kor szerinti elemzés adatai alapján a legtöbb esetben gyermekes nók voltak táppénzen, a férfiak aránya csak az üzemi balesetekkel összefüggésben volt magasabb. 2014 és 2016 között a naponta átlagosan táppénzen lévő nők aránya már 59-60\% volt; a férfiak körében továbbra is az egyéb baleset volt a táppénz igénybevételének fö oka. A korcsoportok szerinti megoszlás nem változott lényegesen. 2014-ben és 2015-ben a 30-34, 2016-ban a 35-39 évesek vették igénybe a leggyakrabban a táppénzellátást.

Következtetés: Megállapítható, hogy a táppénz igénybevételére a foglalkoztatottsági ráta, a táppénz összegére vonatkozó jogszabályi változások és olyan társadalmi tendenciák is hatással vannak, mint a munkaerőhiány okozta helyettesítési nehézségek, a munkahely elveszítésétől való félelem.
\end{abstract}

Orv Hetil. 2019; 160(Suppl 1): 37-42.

Kulcsszavak: táppénz, Egészségbiztosítási Alap, pénzbeni ellátások, táppénzkiadás

\section{Sick-pay trends of the National Health Insurance Fund of Hungary between 1997 and 2017}

Introduction: The role of sick-pay is to compensate for loss of wage in case of incapacity for work, to ensure that there will be no break in the existential state of the incapacitated person.

Aim: The purpose of our research was to examine data on sickness benefit and payroll data for the period 19972017.

Data and methods: Our research was based on the data of the National Health Insurance Fund of Hungary, the Hungarian Central Statistical Office, the State Audit Office of Hungary and the Hungarian State Treasury as well as on the background reports of the European Commission's Social Protection Committee and the Organisation for Economic Co-operation and Development (OECD), and it is based on the legal environment of sick-pay.

Results: In 1997, there were 119000 of 3.558 million, in 1998114000 of 3.530 million, in 1999115000 of 3.433 million, in 2000112000 of 3.465 million, in 2006100000 of 3.523 million, in 201255000 of 3.769 million entitled people on sick leave on average per day. In 2017, the number of entitled persons increased to 4.018 million, while the average number of sick days per day was 70000 . According to data from gender and age-based analysis, in most cases, women with childbearing were on sick-leave, the proportion of males was higher in relation to industrial accident. Between 2014 and 2016, the proportion of women on sick leave per day was 59-60\%, while the major reason for sick-pay among men was the industrial accident. The distribution by age did not change significantly. In 2014-2015, the age-group 30-34, while in 2016 the age-group 35-39 had the highest utilization of sick-pay. 
Conclusion: We can conclude that the use of sick-pay is affected by the employment rate, legal changes affecting the amount of sick-pay and social trends like substitution difficulties due to labor shortages and fear of losing jobs.

Keywords: sick-pay, National Health Insurance Fund of Hungary, cash benefits, sick leave

Nogel M. [Sick-pay trends of the National Health Insurance Fund of Hungary between 1997 and 2017]. Orv Hetil. 2019; 160(Suppl 1): 37-42.

\begin{abstract}
Rövidítések
E. Alap = Egészségbiztosítási Alap; Ebtv. = egészségbiztosítási törvény; KSH = Központi Statisztikai Hivatal; MÁK = Magyar Államkincstár; NEAK = Nemzeti Egészségbiztosítási Alapkezelő (korábbi nevén OEP); OECD = (Organisation for Economic Co-operation and Development) Gazdasági Együttmúködési és Fejlesztési Szervezet; OEP = Országos Egészségbiztosítási Pénztár; ONYF = Országos Nyugdíjbiztosítási Fơigazgatóság; $\mathrm{SPC}=($ Social Protection Committee $)$ Szociális Védelmi Bizottság
\end{abstract}

A táppénz Magyarországon egyike az Egészségbiztosítási Alap (E. Alap) pénzbeni ellátásainak. Intézménye a kötelező betegségbiztosítás megalakulásával egyidejűleg született meg. Jellegzetesen az úgynevezett relatív szociális biztonsági szint elérését szolgálja. Pénzbeli jóléti transzfer, amely biztosítási jogviszonyhoz és járulékfizetéshez van kötve [1].

A rendszerváltásig a gondoskodó állam szerepe meghatározó volt a társadalombiztosításban, az 1980-as évek végére azonban tudatos reformlépéseket tett a jogalkotó ennek visszaszorítására. Már 1989-ben elkezdődött a szolgáltatói és a finanszírozási oldal elkülönítése. Az 1988. évi XXI. törvény létrehozta az önálló, állami költségvetéstől elkülönített, állami garanciát élvező Társadalombiztosítási Alapot [1]. Az állam feladata a deficit finanszírozásához kötődő garanciavállalásra korlátozódott $[2,3]$.

1991-ben a Társadalombiztosítási Alapot két részre bontották: Egészségbiztosítási és Nyugdíjbiztosítási Alapra. A korábban egységes szervezet kettévált, létrejött az Országos Egészségbiztosítási Pénztár (OEP) és az Országos Nyugdíjbiztosítási Főigazgatóság (ONYF), és egyidejűleg megtörtént a területi szervek szétválása is. Az Egészségbiztosítási Alap a létrehozása óta fedezethiányos [4-8]. Az Egészségbiztosítási Alap kezelői ezért szigorú gazdálkodást folytatnak a költségek csökkentése érdekében, ennek keretében a táppénzre vonatkozó szabályozás is változásokon ment át az elmúlt 20 évben [9-11].

A táppénzre vonatkozó hatályos szabályozást az 1997. évi LXXXIII. törvény (Ebtv.) tartalmazza [12]. A táppénzzel kapcsolatos adatokat az igénybevevők egészségi állapota, a gazdasági folyamatok, a társadalmi elvárások, a jogi változások alakítják [13]. A táppénzzel összefüggő társadalmi tendenciák tehát többféle aspektusból vizsgálhatók [14, 15].
Kutatásunk célja a táppénz igénybevételére és a táppénzkifizetésekre vonatkozó adatok feldolgozása volt az 1997 és 2017 közötti időszakra.

\section{Adatok és módszerek}

Kutatásunk a Nemzeti Egészségbiztosítási Alapkezelő (NEAK), korábbi nevén Országos Egészségbiztosítási Pénztár (OEP), a Központi Statisztikai Hivatal (KSH), a Magyar Államkincstár (MÁK) adatsoraira, továbbá az Európai Bizottság Szociális Védelmi Bizottsága (SPC) és a Gazdasági Együttmúködési és Fejlesztési Szervezet (OECD) jelentéseire épül.

A vizsgált időszakra vonatkozóan elemeztük a táppénzre vonatkozó jogszabályi környezet változásait, e körben kiemelt figyelemmel a táppénzre való jogosultság szabályozását, illetve a táppénz összegének alakulását.

Az elemzés keretében vizsgáltuk az E. Alapból az elmúlt húsz évben táppénzre költött kiadásoknak az alakulását. Elemeztük a foglalkoztatottsági adatokat, a táppénzre jogosultak és az igénybe vevők számát, a táppénzen töltött idő hosszának változásait, továbbá a táppénzen töltött idő átlagos hosszának alakulását. Vizsgáltuk a táppénzt igénybe vevők kor és nem szerinti megoszlását is.

A jogszabályok vizsgálatát jog-összehasonlitó módszertannalvégeztük el, ennek keretében a jogszabály-módosítások tartalmát, célját, várt hatását vizsgáltuk. E körben különös figyelmet fordítottunk a táppénz maximális öszszegében, illetve a táppénz mértékében bekövetkezett változások hatásaira az E-Alap kiadásainak, az ellátást igénybe vevőknek és a táppénzen töltött időtartamnak a relációjában.

A magyar egészségbiztosítási rendszer jogi, strukturális és finanszírozási jellegzetességei máshol részletesen bemutatásra kerültek [16-18].

\section{Eredmények}

A táppénz összegének meghatározásakor számos tényezőt kell figyelembe venni, úgymint a biztosítási jogviszony meglétét, illetve hiányát, folyamatosságát, a munkavállaló esetleges munkahelyváltását, korábbi keresőképtelenségét stb. Ezek fényében lehet megállapítani egyrészt az egészségbiztosítási járulékalapot képező jövedelemmel ellátott napok számát, másrészt a jövedelem összegét. A kettő hányadosa adja a táppénz alapját képező napi átlagkeresetet, amelynek adott százalékában kell 
meghatározni a táppénz napi összegét, figyelembe véve annak jogszabályba foglalt felső korlátját. 2009. augusztus 1 -jétől az egy napra járó táppénz maximális összegét a minimálbér négyszeresének harmincadrészében, azaz 9533 forintban (a passzív táppénz esetében 3575 forintban) határozták meg. Ezt a plafont 480 ezer forintos havi átlagos bruttó jövedelem mellett lehetett elérni. A napi táppénz felső korlátja 2010-ben 9800 forintig emelkedett, majd a 2011. május 1-jétől bevezetett szigorítások hatására 5200 forintra esett vissza, a passzív táppénz lehetősége pedig megszünt.

Az egy táppénzes napra jutó átlagos kiadás 2005 és 2009 között - a béremelkedéseknek megfelelően - fokozatosan nőtt, 2420 forintról 3101 forintra. 2010-tól a táppénz összegének csökkentésére irányuló jogszabályváltozások következtében alacsonyabb, közel 2700 forintos értéken stagnált 2012-ig, majd 2013-ban 2929 forintig emelkedett; 2014-ben 3082 Ft, 2015-ben 3247 Ft, 2016-ban 3386 Ft, míg 2017-ben 3752 forint volt. Az E. Alap táppénzre fordított éves kiadása 2005-től 2008-ig 100 milliárd körül mozgott, 2009-ben fizették ki a legtöbb táppénzt az alapból. Ezt követően csökkent a táppénzkiadás, majd 2014-tôl növekedésnek indult, míg 2017-re ismét megközelítette a 100 milliárd forintot (1. táblázat).

A táppénzre való jogosultak számának növekedése nem járt együtt a táppénz gyakoribb igénybevételével.

1. táblázat | A táppénzes kiadások alakulása, 1997-2017

\begin{tabular}{|c|c|c|}
\hline Év & $\begin{array}{l}\text { Táppénzkiadás } \\
\text { (millió Ft) }\end{array}$ & $\begin{array}{c}\text { Egy táppénzes napra jutó } \\
\text { kiadás }(\mathrm{Ft})\end{array}$ \\
\hline 1997 & 36138 & 835 \\
\hline 1998 & 41255 & 989 \\
\hline 1999 & 49205 & 1173 \\
\hline 2000 & 56140 & 1364 \\
\hline 2001 & 64206 & 1508 \\
\hline 2002 & 80864 & 1823 \\
\hline 2003 & 98936 & 2189 \\
\hline 2004 & 96240 & 2457 \\
\hline 2005 & 90484 & 2420 \\
\hline 2006 & 93879 & 2583 \\
\hline 2007 & 91412 & 2772 \\
\hline 2008 & 97860 & 2979 \\
\hline 2009 & 101571 & 3101 \\
\hline 2010 & 74138 & 2662 \\
\hline 2011 & 60501 & 2670 \\
\hline 2012 & 53538 & 2668 \\
\hline 2013 & 57988 & 2929 \\
\hline 2014 & 66462 & 3082 \\
\hline 2015 & 75336 & 3247 \\
\hline 2016 & 85619 & 3386 \\
\hline 2017 & 95341 & 3752 \\
\hline
\end{tabular}

1997 és 2003 között a táppénzesek napi átlagos száma stagnált, majd 2005 és 2013 között csökkent (2005-ben 102 000, 2006-ban 100 000, 2007-2009-ben 90000 , 2010-ben 76 000, 2011-ben 62 000, 2012-ben 55 000, 2013-ban 54000 ), végül 2014-től lassú növekedésnek indult (2014-ben 59 000, 2015-ben 64 000, 2016-ban 69 000, 2017-ben 70 000). E növekedés ellenére a 2017-es szám csak a 2010-es adatokat érte el (1. ábra). A munkavállalók félelme a munkából való kieséstől, állásuk elvesztésétől vagy a helyettesítés megoldatlansága, illetve a keresetkiesés miatt általánosságban a munkavállalók igyekeznek elkerülni a betegállományt.

Elemző kutatásunk során megállapítottuk, hogy 2005-ben egy betegség esetén egy munkavállaló átlagosan 30 napot töltött táppénzen, 2013-ban 6 nappal kevesebbet. A táppénzes időtartam hosszának évenkénti alakulásában a szabályozások szigorításai mellett megmutatkoztak a gazdasági válság hatásai is. Az 1-6 napig tartó táppénzes esetek aránya 2005-ben 32\% volt, és az ennél hosszabb ideig tartó esetek aránya is viszonylag magas: a 7-13 napos időtartam esetén 22 , a 14 naptól 1 hónapig terjedő, illetve az $1-3$ hónapos időtartam esetén 19-19\%. 2009-ben már az esetek 23\%-ában tartott 1-3 hónapig a táppénzes állomány. Bár az utóbbi pár évben a munkavállalók többször kerültek betegállományba, a táppénzes esetek átlagos hossza 2015-ig rövidült, majd

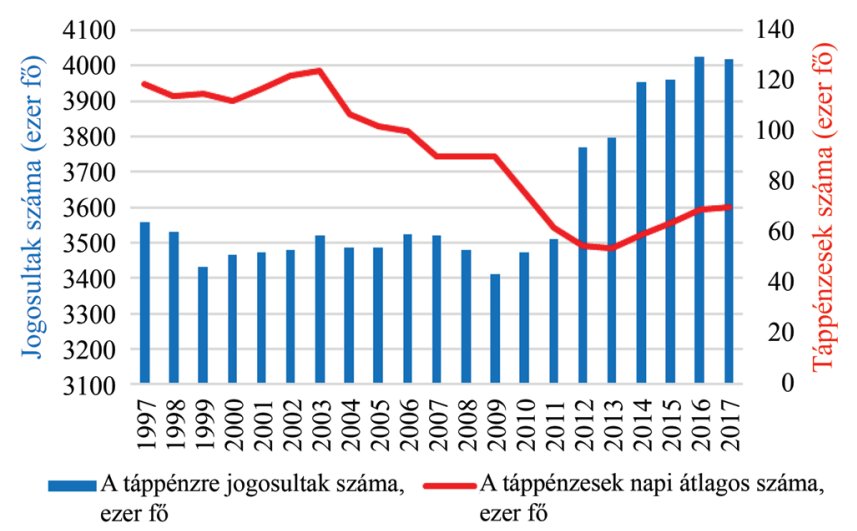

1. ábra A táppénzre jogosultak és a táppénzt igénybe vevők számának alakulása (1000 fó), 1997-2017

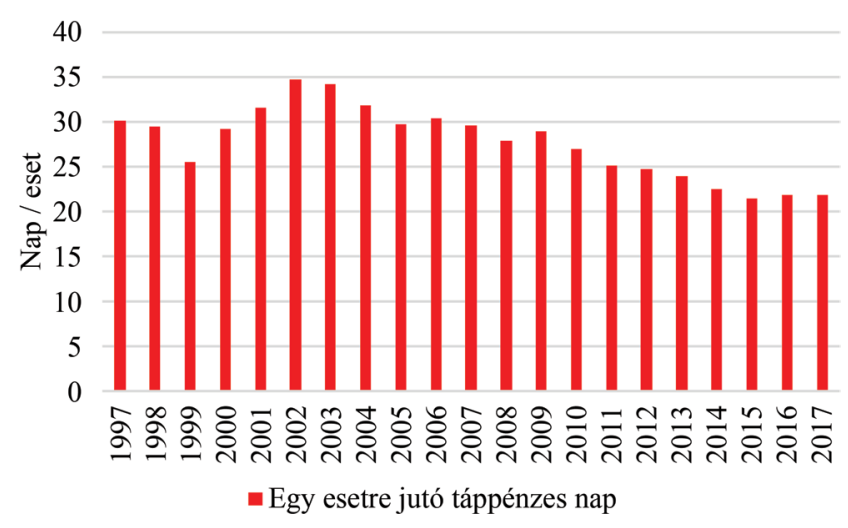

2. ábra | Egy esetre jutó táppénzes napok száma, 1997-2017 

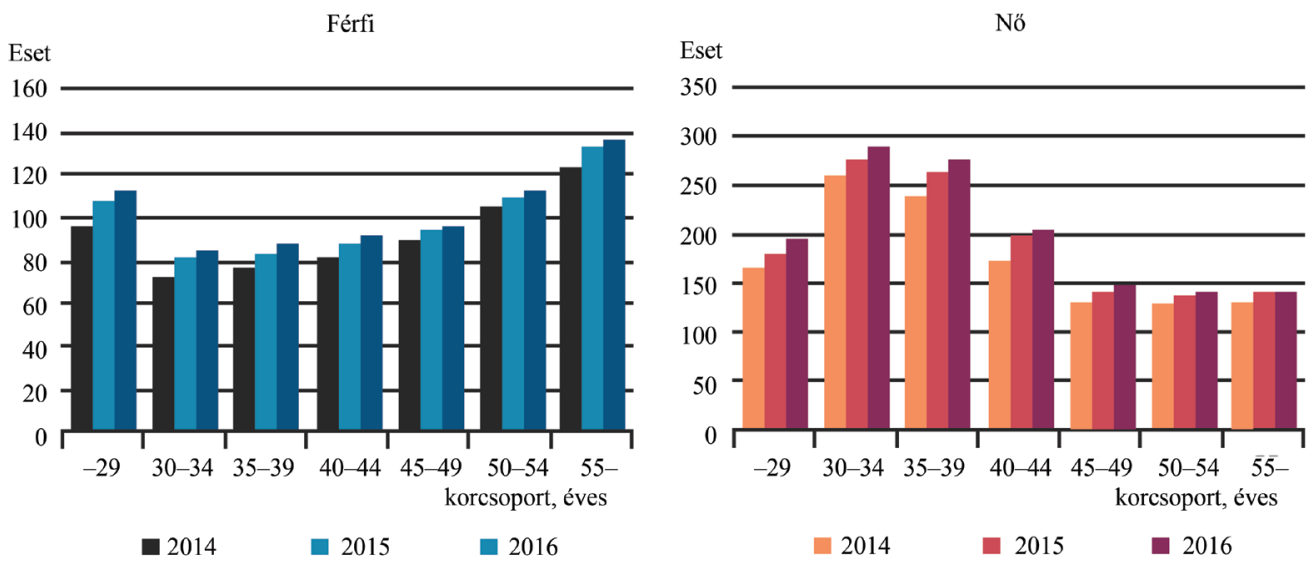

3. ábra | Ezer foglalkoztatottra jutó lezárt táppénzes eset nemek és korcsoportok szerint, 2014-2016

2016-ban az előző évhez hasonlítva I nappal meghoszszabbodott. A lezárt táppénzes eseteket vizsgálva a kevesebb mint egy hétig tartó táppénzes esetek aránya 2009 óta folyamatosan nőtt. Az egy esetre jutó táppénzes napok száma 2006-tól kezdődően egyszer sem haladta meg a 30 napot (2. ábra).

Vizsgáltuk a táppénz igénybevételét a nemek és a különböző korcsoportok szerinti megoszlásban is. A 2000es évek elején megfigyelhető volt az a később is folytatódó tendencia, hogy a férfiakhoz képest a nók 40-56\%-kal többször voltak táppénzen. Ez főként a beteg gyermekük ápolásából adódott, ugyanis tízból kilencszer az anya maradt otthon a gyermek betegsége estében. Megfigyeltük továbbá, hogy a férfiak többször váltak keresőképtelenné üzemi vagy egyéb baleset következtében. 2008-ig több mint kétszer annyi férfit, mint nôt vettek táppénzes állományba emiatt, és a későbbiekben is hasonló volt a két nem megoszlása ezekben a kategóriákban. 2007-tól 2009-ig a 30-34 éves korosztályt érintette a leginkább a táppénz. Ennek egyrészt az az oka, hogy nagyrészt ebben a korcsoportban a legnagyobb a foglalkoztatottság, másrészt ehhez az életkorhoz köthető a gyermekvállalás [19], illetve a betegségük esetén ápolásra szoruló kisgyermekek a családban. 2010-től már a 35-39 éveseké volt a legnépesebb korosztály, egyben a foglalkoztatottak aránya is itt volt a legmagasabb.

Valószínúleg a gyermekvállalás egyre későbbre halasztásának is szerepe lehetett abban, hogy a maximum áttolódott ehhez a korosztályhoz, azaz 2010-től a 35-39 évesek voltak a legtöbbször táppénzen. Az 55-59 éves korcsoport foglalkoztatottsági rátája 2009 óta látványosan emelkedett a többi korcsoportéhoz képest (a 2008as 46,2\%-os mélypontról 2013-ra elérte az 58,4\%-ot). 2014 és 2016 között a naponta átlagosan táppénzen lévő nők aránya már 59-60\% volt; a férfiak körében továbbra is az egyéb baleset volt a táppénz igénybevételének fö oka. A korcsoportok szerinti megoszlás nem változott lényegesen, 2014-ben és 2015-ben a 30-34, 2016-ban a 35-39 évesek vették igénybe a leggyakrabban a táppénzellátást (3. ábra).

\section{Megbeszélés}

Az E. Alap deficites múködése a táppénzkiadások visszaszorítását alapvetően jogi eszközökkel kívánja korrigálni. Az egészségügyi intézmények számára különösen jelentôs kihívás a fiskális szempontoknak történő megfelelés [20-23]. A reálbérek növekedésével a táppénzes kiadások még azokban az években is növekedtek, amikor a táppénzt igénybe vevók száma csökkent.

A NEAK jogelődje, az OEP az 1990-es évek végén indította el részletes táppénzes adatgyúijtési programját [24]. Ezen adatgyújtési rendszer biztosítja az átmeneti keresőképtelenségre vonatkozó betegszintű adatok elérhetőségét. Az egészségügyi ellátórendszer gyógyító és rehabilitációs ellátásainak kiemelt célja az egészség helyreállítása és az átmeneti keresőképtelenség megszüntetése [25-30].

A statisztikai adatok átfogó elemzése alapján megállapítható, hogy a táppénz igénybevételére a foglalkoztatottsági ráta, a táppénz összegére vonatkozó jogszabályi változások és olyan társadalmi tendenciák is hatással vannak, mint a munkaerőhiány okozta helyettesítési nehézségek, a munkahely elveszítésétôl való félelem [31-35].

A vizsgált időszakon belül az igénybe vevők számában és a jogosultakhoz viszonyított arányában, valamint a táppénzes napok és esetek számában először 2007-ben következett be jelentősebb visszaesés, amihez hozzájá-

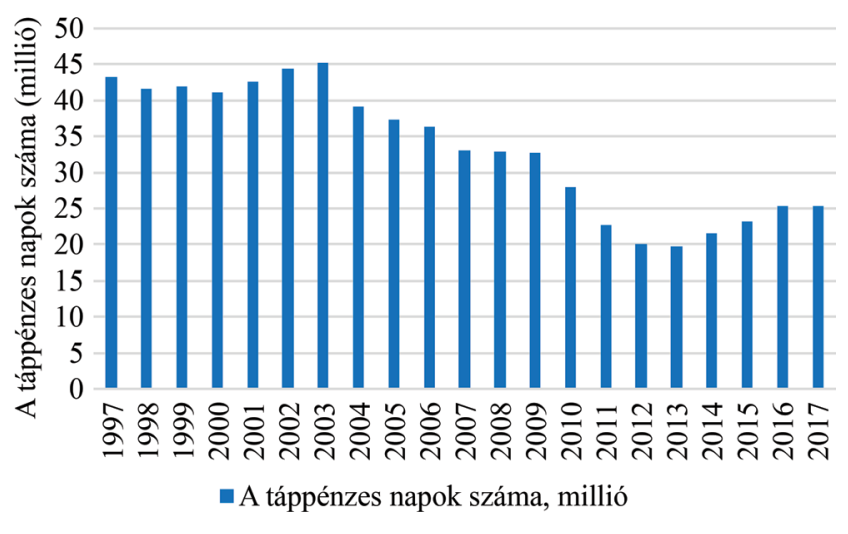

4. ábra $\quad$ A táppénzes napok száma, 1997-2017 (millió nap) 
rulhatott a biztosítási jogviszony megszűnését követően igényelt, úgynevezett passzív táppénz időtartamának 90 napról 45 napra rövidítése [36]. A következő lényeges visszaesés 2010-ben történt: ez összefüggésbe hozható azzal, hogy a táppénz összege a naptári napi átlagjövedelem 70\%-a helyett annak 60\%-a (kórházi ellátás esetén 60 helyett 50\%-a) lett, ami nem haladhatta meg a bevezetett táppénzösszeg-maximumot, valamint 30 napra csökkent a passzív táppénz időtartama [37]. A táppénz igénybevételének egyenletes nagymértékü csökkenése 2012-ig folytatódott. 2011 májusában a táppénz maximális öszszegét a felére csökkentették, 2011 júliusában pedig eltörölték a passzív táppénzt [38]. Ezen változások hatása a 4. ábrán is megfigyelhető. 2015. január 1-jétől módosultak az Ebtv.-ben, valamint az e törvény végrehajtására kiadott 217/1997. (XII. 1.) kormányrendeletben foglalt, az egészségbiztosítás pénzbeli ellátásaival, a baleseti táppénzzel, a méltányossági ellátásokkal kapcsolatos rendelkezések. A táppénzre vonatkozó rendelkezések - a jogosultsági feltételek változatlanul hagyásával - kedvező változásokat hoztak a naptári napi alap meghatározásában. Az új szabályozás alapján a táppénz naptári napi alapját az adóelóleg megállapításához az állami adóhatóságnál bevallott, pénzbeli egészségbiztosítási járulékalapot képező jövedelem képezi.

A jogszabályi változásokon túlmenően a makrogazdasági folyamatok is hatottak a táppénz-igénybevétel adataira. A táppénzre jogosultak száma - amely a biztosítási jogviszony létének követelménye miatt szoros összefüggésben áll a foglalkoztatottak számával - a 2008-ban kezdődött gazdasági válság éveiben jelentősen csökkent, míg 2008 és 2012 között stagnált. 2013-ban a foglalkoztatás növekedésnek indult, ezzel együtt egyre többen váltak jogosulttá a táppénzre.

A táppénzre vétel szokásos egészségügyi okai, a megbetegedések típusai érdemi változást nem mutattak a vizsgált években. A mozgásszervi, felső légúti, cardiovascularis kórképek szerepe meghatározó [39-43], ugyanakkor a szintén népbetegséget jelentő daganatos kórképek nem tartoznak a táppénzre vételi típusos diagnózisok közé [44-49].

A férfiakhoz képest a nők 40-56\%-kal többször voltak táppénzen, ami nagyrészt beteg gyermekük ápolásából adódott, ugyanis tízből kilencszer az anya maradt otthon a kisgyermekével. Megfigyeltük továbbá, hogy a férfiak többször váltak keresőképtelenné üzemi vagy egyéb baleset következtében.

Anyagi támogatás: A közlemény a Magyar Nemzeti Bank Pallas Athéné Innovációs és Geopolitikai Alapítványának (PAIGEO) pályázati támogatásával készült, „A pénzbeli és természetbeni ellátások arányai az Egészségbiztositási Alap költségvetésében a munkaeröpiaci folyamatok tükrében” című 26/2017. (05. 12.) kuratóriumihatározat-számú projekt keretében.
A szerző a cikk végleges változatát elolvasta és jóváhagyta.

Szerzôi érdekeltségek: A szerzőnek nincsenek érdekeltségei.

\section{Irodalom}

[1] Ocskai G. Main social and economic context of sick-pay. Doctoral thesis. [A táppénz fóbb szociális és gazdasági összefüggései. Doktori értekezés.] Kaposvári Egyetem, Gazdaságtudományi Kar, Számvitel és Statisztikai Tanszék, Kaposvár, 2008. [Hungarian]

[2] Kóródi M. Development and functioning of the social security. Entitlement. In: Care and provisions. [A társadalombiztosítás funkcionálása és fejlesztése. Jogosultság. In: Gondoskodás, ellátás.] Marx Károly Közgazdaságtudományi Egyetem, Budapest, 1989; pp. 115-155. [Hungarian]

[3] Sárdi Gy. Sickness and health insurance in Hungary. [A betegségi és egészségbiztosítás Magyarországon.] Országos Egészségbiztosítási Pénztár, Budapest, 2003. [Hungarian]

[4] Boncz I, Sebestyén A. Financial deficits in the health services of the UK and Hungary. Lancet 2006; 368: 917-918.

[5] Boncz I, Nagy J, Sebestyén A, et al. Financing of health care services in Hungary. Eur J Health Econ. 2004; 5: 252-258.

[6] Boncz I, Kaló Z, Mohamed Ibrahim MIB, et al. Further steps in the development of pharmacoeconomics, outcomes research, and health technology assessment in Central and Eastern Europe, Western Asia, and Africa. Value Health Reg Issues 2013; 2: 169170.

[7] Boncz I, Dózsa C, Kaló Z, et al. Development of health economics in Hungary between 1990-2006. Eur J Health Econ. 2006; 7(Suppl 1): S4-S6.

[8] Boncz I, Nagy J, Körösi L, et al. The effect of the introduction of visit fee on the number of patient-visits to outpatient care departments in Hungary. Value Health 2008; 11: A368-A369.

[9] Gulácsi L, Májer I, Boncz I, et al. Hospital costs of acute myocardial infarction in Hungary, 2003-2005. [Az akut myocardialis infarctus kórházi költségei Magyarországon, 2003-2005.] Orv Hetil. 2007; 148: 1259-1266. [Hungarian]

[10] Gresz M, Nagy J, Freyler P. Health related costs of smoking from the viewpoint of the Health Insurance Fund in Hungary. [A dohányzás egészségügyi hatásainak költségei az Országos Egészségbiztosítási Pénztár szemével.] Orv Hetil. 2012; 153: 344-350. [Hungarian]

[11] Iski G, Rurik I. The estimated economic burden of overweight and obesity in Hungary. [Becslések a túlsúly és az elhízás hazai gazdasági terheiről.] Orv Hetil. 2014; 155: 1406-1412. [Hungarian]

[12] Act LXXXIII of 1997 on the services of compulsory health insurance. [1997. évi LXXXIII. törvény a kötelező egészségbiztosítás ellátásairól.] Hatályos jogszabályok gyújteménye, Wolters Kluwer, Budapest. [Hungarian]

[13] Boncz I, Sebestyén A. Economy and mortality in Eastern and Western Europe between 1945-1990: the largest medical trial of history. Int J Epidemiol. 2006; 35: 796-797.

[14] Baji P, Brodszky V, Rencz F, et al. Health status of the Hungarian population between 2000-2010. [A magyar lakosság egészségi állapota 2000 és 2010 között.] Orv Hetil. 2015; 156: 2035-2044. [Hungarian]

[15] Boncz I, Sebestyén A, Döbrössy L, et al. The organisation and results of first screening round of the Hungarian nationwide organised breast cancer screening programme. Ann Oncol. 2007; 18: 795-799.

[16] Gulácsi L, Brodszky V, Péntek M, et al. History of health technology assessment in Hungary. Int J Technol Assess Health Care 2009; 25(Suppl 1): 120-126. 
[17] Boncz I, Sebestyén A, Ember I. Organized, nationwide cervical cancer screening programme in Hungary. Gynecol Oncol. 2007; 106: 272-273.

[18] Boncz I, Brodszky V, Péntek M, et al. The disease burden of colorectal cancer in Hungary. Eur J Health Econ. 2010; 10(Suppl 1): S35-S40.

[19] Egyed J. Changing trends in obstetrics in the last decade. [Az elmúlt évtized változóban lévő szülészeti trendjei.] Orv Hetil. 2012; 153: 1087-1091. [Hungarian]

[20] Endrei D, Molics B, Ágoston I. Multicriteria decision analysis in the reimbursement of new medical technologies: real-world experiences from Hungary. Value Health 2014; 17: 487-489.

[21] Endrei D, Zemplényi A, Molics B, et al. The effect of performance-volume limit on the DRG based acute care hospital financing in Hungary. Health Policy 2014; 115: 152-156.

[22] Boncz I, Nagy J. 10 years of experience with the Hungarian Diagnosis Related Groups (DRG) system. [A Homogén Betegségcsoportok (HBCS) rendszerének 10 éves tapasztalatai finanszírozói oldalról.] Egészségügyi Menedzsment 2003; 5: 21-27. [Hungarian]

[23] Endrei D, Kollár L, Bódis J, et al. Effects of performance-volume limit on the institutional financing of the Clinical Centre of the University of Pécs, Hungary. [A teljesítményvolumen-korlát hatása a Pécsi Tudományegyetem Klinikai Központ intézményi finanszírozására.] Orv Hetil. 2010; 151: 1270-1274. [Hungarian]

[24] Boncz I, Flamis L, Győrvári S. ICD based data collection of sickpay data in County Vas. [BNO alapú keresőképtelenségi adatgyújtés tapasztalatai Vas megyében.] Lege Artis Med. 2002; 12: 315-320. [Hungarian]

[25] Péter I, Jagicza A, Ajtay Z, et al. Balneotherapy in psoriasis rehabilitation. In Vivo 2017; 31: 1163-1168.

[26] Kiss G, Kovácsné VB, Tóth ÁL, et al. Efficiency examination of a 6-month trunk prevention program among recruitment kayakcanoe athletes: a randomized control trial. J Back Musculoskelet Rehabil. 2018 Nov 16. doi: 10.3233/BMR-181297. [Epub ahead of print]

[27] Molics B, Kránicz J, Schmidt B, et al. Utilization of physiotherapy services in case of trauma disorders of the lower extremity in the outpatient care. [A fizioterápiás jellegú tevékenységek igénybevételi mutatói a járóbeteg-szakellátásban az alsó végtag traumatológiai kórképei esetében.] Orv Hetil. 2013; 154: 985-992. [Hungarian]

[28] Sebestyén A, Mester S, Vokó Z, et al. Wintertime surgery increases the risk of conversion to hip arthroplasty after internal fixation of femoral neck fracture. Osteoporos Int. 2015; 26: $1109-1117$

[29] Bergier B, Bergier J, Niźnikowska E, et al. Differences in physical activity and nutrition- and silhouette-related behaviours in male and female students in selected European countries. Ann Agric Environ Med. 2018; 25: 176-181.

[30] Molics B, Boncz I, Leidecker E, et al. Health insurance aspects of physiotherapeutic care of neurology disorders in outpatient care. [A neurológiai kórképek fizioterápiás ellátásának egészségbiztosítási vonatkozásai a járóbeteg-szakellátásban.] Ideggyogy Szle. 2015; 68: 399-408. [Hungarian]

[31] Elmer D, Boncz I, Sebestyén A, et al. Changes in the income of health care professional in Hungary. Value Health 2016; 19: A284.

[32] Kovács G, Endrei D, Elmer D, et al. Trends of sick-pay benefits in Hungary between 2005-2013. Value Health 2015; 18: A531.

[33] Kovács G, Endrei D, Elmer D, et al. Sick-pay expenditures in Hungary according to major disease groups. Value Health 2015; 18: A530.
[34] Pónusz R, Kovács D, Raposa LB, et al. Motivations for foreign employment and carrier change among Hungarian physiotherapists. [Külföldi munkavállalás és pályaelhagyási indítékok a magyar gyógytornászok körében.] Orv Hetil. 2016; 157: 342349. [Hungarian]

[35] Kovács G, Endrei D, Elmer D, et al. Changes of sick-pay expenditures in Hungary between 2005-2013. Value Health 2015; 18: A534.

[36] Act CXXI of 2006 on amending certain laws that underpin the 2007 budget of the Republic of Hungary. [2006. évi CXXI. törvény a Magyar Köztársaság 2007. évi költségvetését megalapozó egyes törvények módosításáról. 15. \$ (4).] Hatályos jogszabályok gyújteménye, Wolters Kluwer, Budapest. [Hungarian]

[37] Act XXXV of 2009 on amending some tax laws and related laws. [2009. évi XXXV. törvény egyes adótörvények és azzal összefüggő egyéb törvények módosításáról. 29. \$.] Hatályos jogszabályok gyúiteménye, Wolters Kluwer, Budapest. [Hungarian]

[38] Act LXXXI of 2011 on the amendment of certain health care related acts. [2011. évi LXXXI. törvény az egyes egészségügyi tárgyú törvények módosításáról.] Hatályos jogszabályok gyüjteménye, Wolters Kluwer, Budapest. [Hungarian]

[39] Sebestyén A, Boncz I, Tóth F, et al. Evaluation of the correlation between risk factors and mortality in elderly patients with femoral neck fracture with 5-year follow-up. [Időskori combnyaktöréseket követő halálozás és kockázati tényezőik kapcsolatának értékelése 5 éves utánkövetéssel.] Orv Hetil. 2008; 149: 493503. [Hungarian]

[40] Apor P. Cardiac rehabilitation and its sporty face. [A szívbetegek rehabilitációjának sportos arca.] Orv Hetil. 2018; 159: 13461352. [Hungarian]

[41] Járomi M, Kukla A, Szilágyi B, et al. Back school programme for nurses has reduced low back pain levels: a randomised controlled trial. J Clin Nurs. 2018; 27: e895-e902.

[42] Németh N, Elmer D, Pónusz R, et al. Burden of disease of acute myocardial infarction in Hungary. Value Health 2018; 21(Suppl 1): S59.

[43] Melczer C, Melczer L, Goják I, et al. Telemetry data based on comparative study of physical activity in patients with resynchronization device. [Reszinkronizációs készülékkel élő betegek fizikai aktivitásának összehasonlító vizsgálata telemetriás adatok alapján.] Orv Hetil. 2017; 158: 748-753. [Hungarian]

[44] Endrei D, Sebestyén A, Gazsó T, et al. Financial issues of obstetrics and gynecology. [A szülészeti-nőgyógyászati ellátás finanszírozási kérdései.] Magy Nőorv L. 2016; 79: 78-81. [Hungarian]

[45] Boncz I, Sebestyén A, Pintér I, et al. Age group-specific gap between treatment cost of and mortality due to breast and colorectal cancer. J Clin Oncol. 2007; 25: 4501-4502.

[46] Boncz I. Prevention of cervical cancer in low-resource settings. JAMA 2006; 295: 1248

[47] Boncz I, Sebestyén A, Döbrôssy L, et al. The role of immunochemical testing for colorectal cancer. Lancet Oncol. 2006; 7 : 363-364.

[48] Horváth CZ, Sebestyén A, Österle A, et al. Economic burden of long-term care of rheumatoid arthritis patients in Hungary. Eur J Health Econ. 2014; 15(Suppl 1): S131-S135.

[49] Boncz I, Endrei D, Ágoston I, et al. Annual health insurance cost of breast cancer treatment in Hungary. Value Health 2014; 17: A735.

(Nogel Mónika dr., Györ, Áldozat u. 12., 9026 e-mail: oktatas@nogel.hu)

A cikk a Creative Commons Attribution-NonCommercial 4.0 International License (https://creativecommons.org/licenses/by-nc/4.0) feltételei szerint publikált Open Access közlemény, melynek szellemében a cikk nem kereskedelmi célból bármilyen médiumban szabadon felhasználható, megosztható és újraközölhető, feltéve, hogy az eredeti szerző és a közlés helye, illetve a CC License linkje és az esetlegesen végrehajtott módosítások feltüntetésre kerülnek 